\title{
EKSPERIMEN PEWARNAAN BATIK DENGAN BAHAN ALAMI DAUN PACAR KUKU DI SMP IT BINA INSAN
}

\author{
Khoirurrahma, Sri Wiratma, Adek Cerah Kurnia Azis \\ Surel : khoirurrahma09@gmail.com
}

\begin{abstract}
This research aims to find out how the process and stages are carried out to make batik colors using natural ingredient pacar kuku leaves, to find out how the results of batik coloring in terms of color evenness, color sharpness, and color absorption using natural ingredient pacar kuku leaves, and to find out how the influence of the time difference for one day, two days and theree days done when soaking batik cloth using natural ingredient pacar kuku leaves (Lawsonia Inermis L). This research is a qualitative research. The research method used is descriptive qualitative method. The population contained in this research were all first year students of Al-Ghazali Class SMP IT Bina Insan, using Purposive Sampling technique, which is a sampling technique with certain considerations. Work evaluation indicators, such as; color evenness, color sharpness, and color absorption as well as the time differences. The results showed that overall the work of batik coloring experiment with natural ingredient pacar kuku leaves (Lawsonia Inermis L) from the time differences for one day, two days and theree days obtained good category result. color evenness overall obtained good category result, color absorption obtained good category result and color sharpness obtained good category result.
\end{abstract}

Keywords : Experiment, Coloring, Leaves

\begin{abstract}
ABSTRAK
Penelitian ini bertujuan untuk mengetahui bagaimana proses serta tahapan yang dilakukan dalam pembuatan warna batik dengan menggunakan bahan alami daun pacar kuku (Lawsonia Inermis L), untuk mengetahui bagaimana hasil pewarnaan batik dari segi kerataan warna, ketajaman warna dan penyerapan warna menggunakan bahan alami daun pacar kuku, dan untuk mengetahui bagaimana pengaruh perbedaan waktu selama satu hari, dua hari dan tiga hari yang dilakukan saat perendaman kain batik bahan alami daun pacar kuku. Penelitian ini termasuk jenis penelitian Kualitatif. Metode penelitian yang digunakan yaitu metode penelitian Deskriptif Kualitatif. Populasi yang terdapat dalam penelitian ini adalah keseluruhan peserta didik kelas VII berjumlah delapan puluh satu peserta didik. Sampel yang digunakan dalam penelitian ini terdiri dari dua puluh empat peserta didik kelas VII Al-Ghazali SMP IT Bina Insan, dengan menggunakan teknik Purposive Sampling yaitu teknik penentuan sampel dengan pertimbangan tertentu. Indikator penilian karya yaitu dari segi kertaan warna, ketajaman warna dan penyerapan warna serta dari segi perbedaan waktu. Hasil penelitian menunjukkan bahwa secara keseluruhan karya dari hasil eksperimen pewarnaan batik dengan bahan alami daun pacar kuku dari segi perbedaan waktu 1 hari, 2 hari dan 3 hari memperoleh kategori baik. Secara keseluruhan kerataan warna memperoleh kategori baik, penyerapan warna memperoleh kategori baik dan ketajaman warna memperoleh kategori baik.
\end{abstract}

Kata Kunci : Eksperimen, Pewarnaan, Daun 

Khoirurrahmah : Eksperimen Pewarna Batik ...

\section{PENDAHULUAN}

Indonesia Negara yang kaya akan sumber daya alam, menuntut kita untuk menggunakannya secara benar, salah satu sumber daya alam yang bisa kita manfaatkan adalah pewarna alam. Sejak zaman dahulu nenek moyang menggunakan warna alam untuk membatik secara turun temurun sampai ditemukan warna sintetis yang dipandang praktis dan ekonomis.

Dengan melihat sisi kekurangan dari warna alam, dan sisi negatif warna sintetis mengundang keinginan untuk meneliti lebih mendalam penggunaan warna alam, karena warna alam lebih aman dan ramah lingkungan. Ide meneliti warna alam diawali dengan studi eksplorasi yaitu membuat ekstrak bahan warna daun pacar kuku (Lawsonia Inermis L). Daun pacar kuku diekstrak menghasilkan banyak warna yang berdekatan. Uji coba yang sederhana ini mengundang rasa penasaran peneliti untuk meneliti lebih rinci dan sistematis. Dengan harapan bila penelitian ini dilakukan secara sistematis dan mendalam menghasilkan warna yang lebih memuaskan.

Kembali ke alam tidak lepas sebagai alasan peneliti. Memanfaatkan zat pewarna alam untuk tekstil menjadi salah satu alternative pengganti zat pewarna bahan kimia. Karena bahan pewarna kimia tersebut dapat mencemari lingkungan. Zat pewarna alam merupakan zat warna yang memenuhi standart kualitas dan aman bagi lingkungan dan kesehatan.

Keunggulan dari zat warna alam yaitu warna yang dihasilkan sangat variatif dan unik, warna cenderung kearah soft. Bahan pewarna alami biasanya terdapat di dalam Tumbuhan atau pun hewan. Bahan pewarna alami ini berupa pigmen yang sudah ada dalam bahan alam atau dibuat melalui proses pemanasan, penyimpanan, atau pemprosesan. Daun pacar kuku dapat diekstrak sebagai pigmen berwarna kuning jingga, dapat digunakan untuk mewarnai bahan katun dan sutera.

Dari hasil pengamatan sebelum melakukan penelitian di sekolah mendapat beberapa permasalahan yang terjadi di sekolah sebagai alasan peneliti menggunakan warna alam dengan bahan alami daun pacar kuku, Siswa hanya mengetahui pewarna batik menggunakan warna sintetis saja, karena selama proses pembelajaran kriya teksil siswa hanya diajarkan cara membatik dan mewarnai dengan bahan sintetis oleh guru prakarya. Ketika pewarna sintetis sedang tidak tersedia dengan alasan tertentu siswa berhenti untuk belajar mewarnai dan hanya belajar mencanting. Disini peneliti berfikir untuk mencari sesuatu supaya membantu permasalahan tersebut.

Peneliti memilih Daun pacar kuku sebagai bahan pewarna alami karena daun pacar kuku dapat digunakan sebagai pewarna batik, dizaman yang modern ini juga 
penggunaan pewarna batik bahan alami daun pacar kuku masih jarang digunakan sebagai pewarna batik, selain itu bahan alami sangat relatif mudah didapatkan sebagai bahan alami untuk membuat warna batik sehingga kita dapat memanfaatkan alam dengan baik, masyarakat masih banyak yang kurang perduli dengan kesehatannya, sehingga peneliti ingin memberi informasi bahwa menggunakan bahan alami daun pacar kuku lebih aman bagi kesehatan manusia, penelitian ini juga dapat membantu menambah pengetahuan siswa tentang bahan alami daun pacar kuku sebagai pewarna batik.

Disini Peneliti akan menjelaskan tentang proses serta tahapan yang akan dilakukan dalam pembuatan pewarna batik dengan menggunakan daun pacar kuku, kemudian peneliti juga mengetahui bagaimana hasil pewarnaan batik dari segi kerataan, ketajaman dan penyerapan warna dengan menggunakan bahan alami daun pacar kuku serta pengaruh perbedaan waktu (Dua puluh empat jam, Empat puluh delapan jam dan Tujuh puluh dua jam) yang digunakan saat perendaman warna kain batik bahan alami daun pacar kuku, dalam penelitian ini peneliti menggunakan dua jenis kain yaitu kain katun prima dan kain katun dobby.

Melihat paparan latar belakang diatas, peneliti tertarik untuk mewujukan keinginan agar menjadi nyata dengan cara eksperimen pewarnaan batik dari bahan alami yaitu menggunakan daun pacar kuku, prosesnya ditinjau berdasarkan perbedaan waktu yaitu satu hari (Dua puluh empat jam), dua hari (Empat puluh delapan jam) dan tiga hari Tujuh puluh dua jam).

Menurut peneliti yang dimaksud dengan eksperimen adalah menguji coba suatu hal secara terencana dan sistematis yang menghasilkan suatu hal yang baru, eksperimen biasanya dilakukan sebagai percobaan untuk membuktikan sesuatu hal tertentu dengan mengontrol variabel.

Menurut peneliti yang dimaksud dengan warna adalah kegiatan yang menyenangkan yang bermanfaat melatih saraf dan kreativitas serta imajinasi dan meliputi semua spectrum warna mencakup warna netral ragam nada, warna juga bisa diaplikasikan pada banyak hal khususnya pada kain batik apabila menggunakan warna alam maka hasilnya nampak bercita rasa tinggi dan lebih cantik.

Berdasarkan pendapat ahli menurut peneliti yang dimaksud dengan batik adalah membuat titiktitik menggunakan alat canting dengan teknik menorehkan malam panas sebagai perintang dengan bermacam motif dan mempunyai ciri khusus.

Menurut peneliti yang dimaksud dengan daun pacar kuku adalah tanaman suku Lythaceae yang merupakan senyawa organik dari Afrika Timur Laut dan Asia Barat Daya, tanaman ini mengandung asam henotanik, zat warna Lawson, 
kelompok pelypenol, sehingga memberikan warna yang baik yaitu merah atau warna coklat kehitaman.

\section{METODE PENELITIAN}

Lokasi penelitian di Sekolah SMP IT Bina Insan di Jl. Nusa Indah Gg. Melati No. 62, Tanjung Sari Sena, Kec. Batang Kuis, Kabupaten Deli Serdang, Sumatera Utara 20372. Metode yang digunakan dalam penelitian ini adalah metode deskripsi kualitatif. Teknik pengumpulan data yang digunakan adalah participant observation (observasi berperan serta), maka peneliti harus berinteraksi langsung dengan sumber data. Adapun populasi pada penelitian ini yaitu siswa/i kelas VII SMP IT Bina Insan Batang Kuis sebanyak tiga kelas yaitu kelas VII Maryam yang berjumlah tiga puluh lima peserta didik, Kelas VII Bilal Bin Rabbah yang berjumlah dua puluh satu peserta didik, dan kelas VII AlGhazali yang berjumlah dua puluh empat peserta didik. Keseluruhan siswa pada kelas VII adalah delapan puluh peserta didik. Peneliti menggunakan teknik proporsive sampling (bertujuan). Maka sampel dalam penelitian ini adalah siswa/i kelas VII Al-Ghazali SMP IT Bina Insan diteliti sebanyak dua puluh empat peseta didik. Dalam penelitian ini, instrument penelitian yang digunakan sebagai alat bantu eksperimen adalah buku catatan, kamera, laptop dan buku pedoman. Peneliti menggunakan teknik pengumpulan data sebagai berikut observasi, dokumentasi, wawancara atau interview.

\section{HASIL PENELITIAN DAN PEMBAHASAN}

Berdasarkan teori yang berkaitan dengan eksperimen pewarna batik dengan bahan alami daun pacar kuku disini peneliti akan menjelaskan bagaimana proses awal pembuatan warna batik dengan bahan alami daun pacar kuku. Langkah pertama yang dilakukan peneliti adalah menjelaskan alat, bahan dan proses untuk membuat warna alami daun pacar kuku, pemotongan kain, pembuatan desain, dimana sebuah desain berkaitan dengan ornament.

Proses selanjutnya setelah proses desain yaitu proses mordanting menggunakan tawas dan soda abu, proses pembuatan ekstrak bahan alami dengan pengeringan bahan dan pelembutan bahan, proses perendaman kain dengan TRO kemudian lanjut perendaman ekstrak bahan selama satu hari, dua hari, dan tiga hari, proses terakhir yaitu proses fiksasi dengan kapur sirih dan proses pelorodan dengan waterglass. Setelah selesai kemudian kain dicuci dengan air bersih dan dikeringkan.

Dalam sebuah analisi data, tentunya akan memproleh hasil disebuah percobaan dalam berbagai hal dimana hasil merupakan nilai yang diproleh seseorang setelah mengikuti pembelajaran (Kartono, 2019 : 130).

Analisis data hasil penelitian eksperimen pewarnaan batik dengan 
bahan alami daun pacar kuku (Lawsonia Inermis L) di SMP IT Bina Insan Kelas VII Al-Ghazali T.A 2020/2021. Berdasarkan aspek penilaian kerataan warna, ketajaman warna dan penyerapan warna, karya peserta didik dinilai oleh satu dosen yaitu : Bapak Adek Cerah Kurnia Azis, S.Pd, M.Pd, dua guru yaitu Muhammad Reza, dan guru serta pengrajin batik yaitu : Siti Sarah Sitakar S.Pd. Hasil analisis dari lembar pengamatan penilaian secara umum menunjukkan secara umum hasil karya eksperimen pewarnaan batik dengan bahan alami daun pacar kuku (Lawsonia Inermis L) di SMP IT Bina Insan Kelas VII Al-Ghazali mendapat predikat Baik. Penilaian terhadap ketiga nilai perbedaan waktu tersebut secara umum mendapat jumlah nilai dua ratu lima pulluh tiga dengan jumlah rata-rata $\left(\sum \mathrm{N}\right)(\mathrm{r})$ delapan puluh empat (Baik).

\section{Pembahasan}

Berdasarkan data yang telah diambil dari ketiga tim penilai yang sudah dideskripsikan secara umum maka hasil data tersebut akan dibahas serta dideskripsikan secara rinci dan jelas satu persatu, sesuai dengan penilaian dan pengamatan karya yang telah dilakukan oleh tim penilai karya pada eksperimen pewarnaan batik dengan bahan alami daun pacar kuku (Lawsonia Inermis L) di SMP IT Bina Insan Kelas VII Al-Ghazali T.A 2019/2020.

Berikut ini adalah penjelasan hasil karya siswa yang akan dibahas mewakili karya sampel (dua puluh empat siswa) sebanyak tiga karya secara satu-persatu berdasarkan hasil penilaian secara umum.

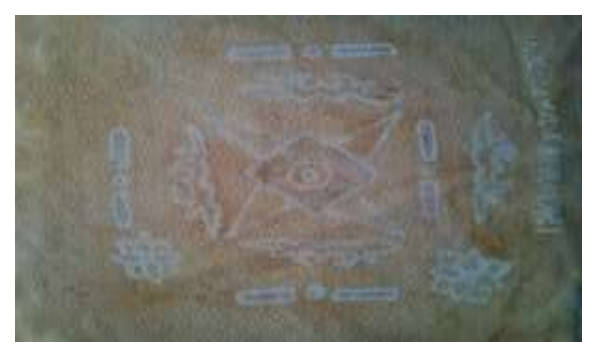

Gambar 1. Pewarnaan batik dengan bahan alami daun pacar kuku selama perendaman satu hari

Proses pewarnaan pada karya ini dengan waktu satu hari (dua puluh empat Jam), terdapat masalah yang berarti, karena hasil warna motif tidak terlihat jelas, warna kain hampir pudar. Pada saat proses pewarnaan peserta didik kurang sering membolak-balik kain sampai warnanya hampir luntur terdapat warna yang tidak merata. Meskipun demikian karya ini memiliki motif yang rapi dan warnanya baik hanya saja terjadi permasalah yang justru terlihat kurang baik pada penyerapan dan kerataan warna. karya ini milik peserta didik bernama Iskandar Zulkarnain.

Setelah data dikumpulkan dan dianalisis secara umum diketahui bahwa indikator dari ketiga penilaian pada karya Iskandar Zulkarnain memiliki nilai yang baik dengan jumlah nilai dua ratus lima puluh dengan rata-rata (r) delapan puluh tiga kategori (Baik). Berikut adalah deskripsi karya berdasarkan indikator penilaian warna.

Kerataan warna dengan nilai dua ratus empat puluh lima rata-rata 
delapan puluh dua dengan kategori (Baik) yaitu memiliki warna yang merata atau kerataan warna bagus, tidak memiliki perbedaan warna, menghasilkan warna yang sama/tidak bercak-bercak, tetapi karya ini memiliki kerataan warna yang sedikit tidak merata dan terdapat sedikit bercak bercak kain.

Kemudian dari segi ketajaman warna memiliki nilai yang baik dengan jumlah nilai dua ratus lima puluh dua rata-rata delapan puluh empat dengan kategori (Baik) yaitu, Memiliki warna yang variatif kuat, variasi warna yang natural dan memiliki warna cerah atau warna gelap, warna Motif terlihat jelas, tetapi dalam ketajaman warna disini karya tidak memiliki warna cerah atau gelap secara baik dan warna motif yang kurang terlihat dengan jelas.

Selanjutnya penyerapan warna memiliki jumlah nilai dua ratus lima puluh satu dengan ratarata delapan puluh empat dengan kategori (Baik), indikator penyerapan warna yaitu, warna menyerap dengan baik, warna menyerap keseluruh kain, warna tidak mudah luntur, akan tetapi pada karya ini warna menyerap kurang baik dan tidak menyerap keseluruh kain, sehingga saat dilorod warna kain sedikit memudar.

Berdasarkan penguraian nilai rata-rata setiap indikator penilaian pada karya Iskandar Zulkarnain dikategorikan baik (B), namun dikatakan masih kurang sempurna berdasarkan penyerapan warna dan kerataan warna.

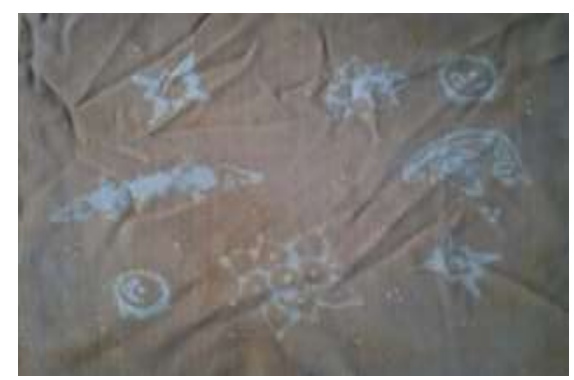

Gambar 2. Pewarnaan batik dengan bahan alami daun pacar kuku selama perendaman dua hari

Proses pewarnaan pada karya ini dengan waktu dua hari (empat puluh delapan Jam), terdapat masalah yang tiada berarti, karena warna kain masih kurang rata dan motif kurang terlihat. Meskipun demikian karya ini memiliki motif yang rapi dan warnanya baik hanya saja terjadi permasalah yang justru terlihat kurang baik pada kerataan warna. karya ini milik peserta didik bernama Althaaf Nugroho.

Setelah data dikumpulkan dan dianalisis secara umum diketahui bahwa indikator dari ketiga penilaian pada karya Althaaf Nugroho memiliki nilai yang baik dengan jumlah nilai dua ratus lima puluh enam dengan rata-rata (r) delapan puluh lima kategori (Baik). Berikut adalah deskripsi karya berdasarkan indikator penilaian warna.

Kerataan warna dengan nilai dua ratus lima puluh dua rata-rata delapan puluh empat dengan kategori (Baik) yaitu memiliki warna yang merata atau kerataan warna bagus, tidak memiliki perbedaan warna, 
menghasilkan warna yang sama/tidak bercak-bercak, tetapi karya ini memiliki kerataan warna yang sedikit tidak merata.

Kemudian dari segi ketajaman warna memiliki nilai yang baik dengan jumlah nilai dua ratus lima puluh enam rata-rata delapan puluh lima dengan kategori (Baik) yaitu, memiliki warna yang variatif kuat, variasi warna yang natural dan memiliki warna cerah atau warna gelap, warna Motif terlihat jelas, tetapi dalam ketajaman warna disini karya pada bagian warna motif yang kurang terlihat dengan jelas.

Selanjutnya penyerapan warna memiliki nilai yang baik dengan jumlah dua ratus enam puluh satu dengan rata-rata delapan puluh tujuh dengan kategori (Baik), indikator penyerapan warna yaitu, warna menyerap dengan baik, warna menyerap keseluruh kain, warna tidak mudah luntur, akan tetapi pada karya ini warna tidak menyerap keseluruh kain, sehingga saat dilorod warna kain sedikit memudar.

Berdasarkan penguraian nilai rata-rata setiap indikator penilaian pada karya Althaaf Nugroho dikategorikan baik (B), namun dikatakan masih kurang sempurna berdasarkan penyerapan warna dan kerataan warna.

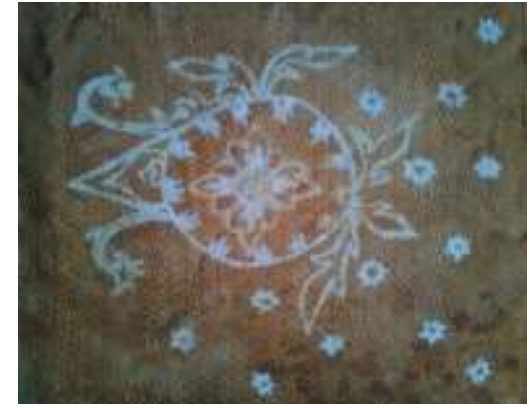

Gambar 3. Pewarnaan batik dengan bahan alami daun pacar kuku selama perendaman tiga hari

Proses pewarnaan pada karya ini dengan waktu tiga hari (tujuh puluh dua Jam), terdapat masalah yang tiada berarti, karena hasil warna kurang merata dan terdapat bercakbercak pada kain. Meskipun demikian karya ini memiliki motif yang rapi dan warnanya baik hanya saja terjadi permasalah yang justru terlihat kurang baik pada kerataan warna. karya ini milik peserta didik bernama Arif Rahman.

Setelah data dikumpulkan dan dianalisis secara umum diketahui bahwa indikator dari ketiga penilaian pada karya Arif Rahman memiliki nilai yang baik dengan jumlah nilai dua ratus enam puluh satu dengan rata-rata (r) delapan puluh tujuh kategori (Baik). Berikut adalah deskripsi karya berdasarkan indikator penilaian warna.

Kerataan warna dengan nilai dua ratus empat puluh empat ratarata delapan puluh satu dengan kategori (baik) yaitu memiliki warna yang merata atau kerataan warna bagus, tidak memiliki perbedaan warna, menghasilkan warna yang sama/tidak bercak-bercak, tetapi karya ini memiliki warna yang 
sedikit tidak merata dan terdapat sedikit bercak bercak kain.

$$
\text { Kemudian dari segi }
$$

ketajaman warna memiliki nilai yang baik dengan jumlah nilai dua ratus enam puluh tujuh rata-rata delapan puluh sembilan dengan kategori (baik) yaitu, memiliki warna yang variatif kuat, variasi warna yang natural dan memiliki warna cerah atau warna gelap, warna Motif terlihat jelas, tetapi dalam ketajaman warna disini karya tidak memiliki variasi warna yang natural.

Selanjutnya penyerapan warna memiliki nilai yang baik dengan jumlah dua ratus tujuh puluh tiga dengan rata-rata Sembilan puluh satu dengan kategori (Sangat baik), indikator penyerapan warna yaitu, warna menyerap dengan baik, warna menyerap keseluruh kain, warna tidak mudah luntur. Semua indikator penilaian terpenuhi dengan sangat baik.

Berdasarkan penguraian nilai rata-rata setiap indikator penilaian pada karya Arif Rahman dikategorikan baik (B), namun dikatakan masih kurang sempurna berdasarkan kerataan warna.

\section{SIMPULAN}

Berdasarkan pembahasan
data dan penelitian yang telah
diperoleh maka dapat diambil kesimpulan bahwa: Proses serta tahapan dalam pewarnaan batik dengan bahan alami daun pacar kuku yaitu dimulai dari persiapan alat dan bahan, kemudian proses pencantingan selanjutnya proses mordanting dengan tawas, soda abu dan air, proses selanjutnya yaitu ekstrak bahan daun pacar kuku yang sudah dibersihkan, dijemur hingga kering lalu dihaluskan, kemudian masuk dalam proses pewarnaan dengan cara merendam dilarutan TRO terlebih dahulu baru direndam dengan ekstrak bahan daun pacar kuku selama satu sampai tiga hari, dan proses yang terakhir yaitu fiksai dengan kapur, setelah selesai kemudian dilorod dengan waterglass dan air lalu keringkan.

Proses dari membuat ekstrak pewarna daun pacar kuku yang menghasilkan warna untuk perendaman satu hari menghasilkan warna kuning pudar, perendaman dua hari menghasilkan warna kuning kecoklat-coklatan dan perendaman tiga hari menghasilkan warna coklat kemerah-merahan. Dalam proses ini perbedaan kain yang digunakan juga memiliki perbedaan warna, penggunaan kain katun prima menghasilkan warna lebih gelap sedangkan penggunaan kain dobby menghasilkan warna lembut (soft).

Hasil pewarnaan batik karya peneliti menghasilkan warna kuning pudar, kuning kecoklat-coklatan, dan coklat kemerah-merahan. Disini peneliti menggunakan bahan pewarna alami daun pacar kuku, peneliti menggunakan kapur sirih sebagai fiksasi atau pengunci warna, peneliti juga menggunakan mordant tawas dan soda abu. Masalah yang dialami peneliti adalah proses perendaman warna daun pacar kuku harus berulang kali dilakukan untuk 
mendapatkan hasil yang maksimal. Pada tahap akhir pelorotan warna daun pacar kuku pudar sehingga dapat dilihat pada hasil eksperimen, pada tahap akhir pelorotan warna daun pacar kuku tidak menghasilkan warna merah kecoklatan melainkan bewarna kuning pudar sampai dengan warna coklat kemerahmerahan.

Hasil pewarnaan dengan bahan alami daun pacar kuku berdasarkan data dari penilaian tiga tim penilai karya secara umum sebagai berikut: Penilaian kerataan warna memperoleh jumlah nilai dua ribu empat belas dengan rata-rata(r) delapan puluh empat (Baik), Penilaian ketajaman warna memperoleh jumlah nilai dua ribu empat puluh empat dengan ratarata(r) delapan puluh lima (Baik), dan Penilaian penyerapan warna memperoleh jumlah nilai dua ribu empat belas dengan rata-rata(r) delapan puluh empat (Baik).

Pengaruh perbedaan waktu (dua puluh empat jam, empat puluh delapan jam dan tujuh puluh dua jam) yang digunakan saat perendaman warna kain batik bahan alami daun pacar kuku yaitu berpengaruh terhadap hasil warna, semakin lama kain direndam dengan bahan alami warna akan semakin gelap dan tajam tetapi sesuai dengan proses yang ditentukan dengan kata lain salah satunya harus sering dibolak-balik, diangkat dan tiriskan sebentar kemudian rendam lagi dan seterusnya. Berdasarkan hasil penilaian dari ketiga tim penilai secara umum sebagai berikut : Untuk perendaman hasil pewarnaan berdasarkan waktu dua puluh empat Jam mendapatkan jumlah $\left(\sum \mathrm{N}\right)$ empat ratus Sembilan puluh tujuh rata-rata delapan puluh tiga, untuk perendaman hasil pewarnaan berdasarkan waktu empat puluh delapan Jam mendapatkan Jumlah tujuh ratus lima puluh enam Ratarata delapan puluh empat, dan untuk perendaman hasil pewarnaan berdasarkan waktu tujuh [uluh dua Jam mendapatkan jumlah tujuh ratus tujuh puluh satu Rata-rata enam puluh tiga.

\section{DAFTAR RUJUKAN}

Anisa, A., Kartono, G., Mesra, M., \& Wiratma, S. 2018. Analisis Gambar Flora Karya Siswa Kelas Vii Smp Negeri 36 Tahun Ajaran 2017/2018 Berdasarkan Unsur-Unsur Visual. Gorga: Jurnal Seni Rupa, 7(2), 276-283.

Brina, Elsha. 2018. 33 Daun Dahsyat

Tumpas Berbagai Macam

Penyakit. Yogyakarta: C-Klik Media.

Gratha, Benny. 2012. Panduan Mudah Belajar Membatik. Jakarta Selatan: Demedia Pustaka Agromedia Pustaka.

Kamala, N., \& Adriani, A. 2019. Studi Tentang Motif Dan Pewarnaan Batik Cap Dengan Zat Pewarnaan Alam Di Rumah Batik Dewi Busana Kecamatan Lunang Kabupaten Pesisir Selatan. Gorga: Jurnal Seni Rupa, 8(2), 303-307. 
Khoirurrahmah : Eksperimen Pewarna Batik ...

Kartono, G., Mesra, M., \& Azis, A. C. K. 2019. Pengembangan Media Ajar Grafis Komputer Materi WPAP Dalam Bentuk E-Book Dan Video Tutorial Bagi Mahasiswa Seni Rupa. Gorga: Jurnal Seni Rupa, 9(1), 127-132.

Kwartiningsih, Endang. 2011. Zat Warna Alami Tekstil Dari Kulit Buah Manggis Universitas Negeri Semarang. Jurnal Ekuilibrium, 8(1), 41-47.

Paresti, Suci Et All. 2017. Prakarya. Solo: Tiga Serangkai Pustaka Mandiri

Payadnya, Ade Andre I Putu Dan Jayantika, Agung Ngurah Trisna I Gusti. 2018. Panduan Penelitian Eksperimen Beserta Analisis Statistik Dengan Spss. Yogyakarta: Budi Utama

Ranu Handoko, n'Doru. 2008.

Teknik Dasar Mewarnai Dengan Cat Air. Jakarta Selatan: Wahyumedia

Rosso \& Heni Nur'Afni. 2008. Pesona Batik Warna Alam. Jakarta: Gramedia Pustaka Utama

Sari, Pandan Rina. 2013. Ketrampilan Membatik Untuk Anak. Surakarta: Arcita Pustaka Baru

Sukmadinata, Syaodih Nana. 2015. Metode Penelitian Pendidikan. Bandung: Remaja Rosdakarya Siregar, S. A., Sugito, S., \& Atmojo, W. T. 2019. Hubungan Pengetahuan Dan Kemampuan Mendisain Ornamen Dengan Hasil Belajar Membatik Motif
Ornamen Batak Angkola Mandailing Siswa Kelas X SMK Karya Bunda Medan. Gorga: Jurnal Seni Rupa, 8(2), 363-368.

Wong, Waciu. 1986. Beberapa Asas Merancang Warna. Bandung: ITB. 